\title{
Energy Performance Evaluation of Two Automotive-Part Manufacturer Based On Astra Green Energy Rating System
}

\author{
Telaga Abdi Suryadinata ${ }^{1,2 *}$ \\ ${ }^{1}$ Politeknik Manufaktur Astra, Informatics Management Department, Komp. Astra International Tbk Gedung B Jl. Gaya Motor Raya no \\ 8 Sunter II Jakarta 14330, Indonesia \\ ${ }^{2}$ Politeknik Manufaktur Astra, Building Construction Engineering Department, Komp. Astra International Tbk Gedung B Jl. Gaya Motor \\ Raya no 8 Sunter II Jakarta 14330, Indonesia
}

\begin{abstract}
Energy audit is essential to reduce energy consumption for a sustainable industry. Cost reduction through energy saving benefits the industry to stay competitive in the market and reducing its carbon footprint. Manufacturing industry energy usage is characterized by high consumption in heating and cooling process. The paper presents the walk-through audit results of two automotive-part manufacturing companies. Both companies are categorized as small and medium companies that consume energy below 6000 toe/year. Firstly, companies submitted document to the auditor. Desktop evaluation was performed to calculate and rate current energy performance rating. Then, a walk-through audit was performed to finalize the companies energy performance rating based on Astra green energy rating system. Analysis based on companies energy performance indicators are presented to show potential energy saving.
\end{abstract}

\section{Introduction}

Industrial sector shares significant energy consumption of world's energy consumption, consuming around 54\%. The world energy consumption will increase $28 \%$ from 2015 to 2040 [1]. Therefore, the impact of the consumption greatly affects energy resources and emission contribution.

Industrial sector consumption is categorized into 3 subsectors: nonmanufacturing, energy-intensive manufacturing and nonenergy-intensive manufacturing [1]. Automotive manufacturing industry is categorized under energy-intensive manufacturing due to metal processing which requires much energy for heating and cooling process. Therefore, energy consumption in automotive industry is crucial for company sustainability as the energy usage contributes significantly to total production cost. However, many companies often fail to notice excessive energy consumption [2] due to process complexity, high initial investment, long payback period, etc.

Traditionally, energy efficiency objective has been a priority for automotive industry [3]. Pressure to stay competitive in term of quality, cost, on time deliveries, and flexibility push the company to make improvement constantly. Particularly for automotive component manufacturers, as part of automotive supply chain in the region, failure to meet the cost and quality required by corporation could jeopardise their business. In a global supply chain, an OEM product can be substituted from other company's OEM product from same region.
Although manufacturers constantly improve efficiency of energy usage, but most energy management in the companies are still traditional. Many automotive component manufacturers in Indonesia still use machine from 1990's technology. Moreover, current emission reduction goal in Indonesia is to cut carbon emission by $29 \%$ in 2030 [4]. Therefore, energy efficiency improvements in the companies also have to consider carbon emission.

High initial investment cost for new machine and matured process in manufacturing companies make replacement of old machines are less favourable. Fluctuation of demand also contributes for new machines investment decision. The companies are less likely to invest new machines unless future demand for their products is positive.

While, recent machines have smart technology capable to provide real time energy consumption data, capturing data from old machines require laborious work. The company has to assign dedicated persons to manually collect energy information. The dedicated persons usually are part of maintenance team, as the companies try to utilise their resource efficiently. The condition is less ideal to capture all the data needed to make significant energy efficient improvement.

Standardized data, method and analysis are mandatory to compare energy performance among companies [5]. A standardized energy management performance rating can be utilised as a feedback for companies' energy management improvement. Continues evaluation to capture energy management practices in the companies is essential [6]. Companies

Corresponding author: abdi.telaga@polman.astra.ac.id 
under one corporation can learn each other and share their best practice to reduce energy consumption, improve their energy management eventually increase their energy performance rating.

The research paper presents utilisation of corporate energy performance rating to improve energy efficiency of companies. Case study from two automotive part companies are analysed to show comparison and potential energy saving. However, the companies names are not disclose for confidentiality. Both companies energy consumption are under 6000 toe (tonne of oil equivalent) per year. The companies characterised by metal processing through heating and cooling treatment and produce various automotive parts. While the parts produced from both companies are not the same, but the energy consumption level and production process are similar. The research contributes to show benefit of corporate energy performance rating system for energy efficiency improvement.

\section{Methodology}

Astra green energy rating is energy performance rating system developed by Astra International Tbk corporation for all affiliated companies. Evaluation on documents and on-site verification are used in the process. Firstly, companies submitted document to the auditor. Auditor performed desktop evaluation to calculate and rate current energy performance rating. Then, a walk-through audit was performed to finalize the companies energy performance rating based on Astra green energy rating system.

\subsection{Desk Evaluation}

Desk evaluation objective is to evaluate energy reports and documents submitted by affiliated companies. Auditors, then evaluate the energy performance based on:

- Organisation: dedicated organisation for energy management; company energy policy; company energy regulation; energy resources identification; energy usage and system identification.

- Planning: energy performance indicator, energy saving potential identification; planning, target, and energy management program.

- Implementation: training, personnel competencies, and awareness; communication; documentation and document control; design and operational control; procurement of energy related services and equipment.

- Monitoring: Measurement and monitoring; internal audit; obedience with regulation and governance evaluation; non conformity, corrective and prevention action; energy data recapitulation and control.

- Review: Management review; Follow-up action; company support; energy saving success story.
The auditor gives score in 1-100 percentage scale for each category.

\subsection{Walk-through Audit}

Following desk evaluation, auditors performed walkthrough audit to verify and evaluate energy management system, energy consumption and cost, performance of energy related machines/equipment, and energy efficiency potential or implementation. In this stage auditor performs verification based on submitted documents. However, auditors also can check any unreported energy related data if they found the data are necessary. Auditor can adjust the score following on-site facts finding.

\subsection{Final rating}

Calculation of AGen score is straight forward as presented in equation 1. Auditors calculate average value of organisation, planning, implementation, monitoring, and review. The final value than is converted into rating that is shown in table 1 .

$$
R=\frac{R_{o+} R_{p+} R_{i+} R_{m+} R_{r}}{5}
$$

$\mathrm{R}=$ Final score.

$\mathrm{R}_{\mathrm{o}}=$ Organisation score.

$\mathrm{R}_{\mathrm{p}}=$ Planning score.

$\mathrm{R}_{\mathrm{i}}=$ Implementation score.

$\mathrm{R}_{\mathrm{m}}=$ Monitoring score.

$\mathrm{R}_{\mathrm{r}}=$ Review score.

\begin{tabular}{|c|c|}
\hline Table 1. Grade Categories \\
\hline Average & Rating \\
\hline $74-100 \%$ & A \\
\hline $34-73 \%$ & B \\
\hline $0-34 \%$ & C \\
\hline
\end{tabular}

\section{Results}

Final score for both companies are presented in table 2 . The final score are $95 \%$ and $66.4 \%$ for company $\mathrm{B}$ respectively. Those values correspond to grade A and B.

Table 2. Final Score

\begin{tabular}{|c|c|c|}
\hline & Company A & Company B \\
\hline Organisation & $96 \%$ & $64 \%$ \\
\hline
\end{tabular}




\begin{tabular}{|c|c|c|}
\hline Planning & $100 \%$ & $76 \%$ \\
\hline Implementation & $85 \%$ & $63 \%$ \\
\hline Monitoring & $94 \%$ & $72 \%$ \\
\hline Review & $100 \%$ & $57 \%$ \\
\hline
\end{tabular}

\section{Analysis}

Company A receives grade A energy performance that means the company has integrated energy management and energy efficiency into its business strategy to increase its competitiveness and business sustainability. The company also has implemented comprehensive energy management. All the employee and management are aware of energy efficiency and actively support energy management program in the company.

Company $\mathrm{B}$ receive grade $\mathrm{B}$ energy performance that means the company has integrated energy management and energy efficiency into its business strategy. However, the company does not have comprehensive energy management system. Further, the company has to increase energy management and efficiency awareness from stakeholders.

\section{- Organisation}

Company A has dedicated energy management team. The team is not only consisting of maintenance personnel, but also from health and safety department. The whole team is directed by upper management level personnel. Further, the company has clear vision about their energy performance and energy policy. The company also has mapped their energy usage, energy resources, and energy system.

Company B does not have dedicated energy management team. The tasks are handled by maintenance personnel. Company B has clear energy vision of their energy performance and energy policy. However, on-site observation found that the company does not truly implement the policy. The company has mapped their energy usage, energy resources, and energy system

\section{- Planning}

Company A has defined energy performance KPI, 5 years KPI target, yearly KPI target, and set program to achieve the target.

Company B also has defined energy performance KPI, 5 years KPI target, yearly KPI target, and set program to achieve the target. However, the company does not have adequate resources to achieve the target. Lack of personnel and utilisation of old machines make achieving the target is impossible.

\section{- Implementation}

Company A has certified auditor personnel, regularly campaign energy consumption awareness, and complete standard operation procedure (SOP) and documentation of maintenance and operation. The company also has procedure to include energy consumption and carbon emission when procuring new machines or services.

Company B has certified auditor personnel and regularly campaign energy consumption awareness. However, several documents of electrical power system are missing or not updated. The company also still does not have green energy procurement procedure.

\section{- Monitoring}

Company A has implemented real time energy monitoring IT system. Therefore energy data are readily available and energy audit can easily performed regularly. Further, system can alarm maintenance personnel should energy problem occurred. The IT system benefits corrective and prevention process. However, the personnel in charge do not have adequate knowledge to analyse problem in energy system.

Company B does not have real time energy monitoring IT system due to old machine. Therefore, the personnel have to collect data manually. Regular monitoring and analysis of energy data occasionally missed due to incomplete data.

- Review: Management review; Follow-up action; company support; energy saving success story.

Company A energy management team is led by upper management personnel. Therefore management review is regularly held. Any problems are discussed and followup action to solve problems or initiates new programs are supported by company.

Company B occasionally held management review as part of maintenance program. The company is does not adequately support energy efficiency projects.

\section{Conclusion}

Company A has nearly perfect score in all aspects. The company missed detail target and scope of energy policy. Further, during on-site observation on implementation, one circuit breaker current setting was found larger than incoming current. Therefore, the breaker cannot function properly. The company A has implemented real time energy monitoring system, however personnel in charge does not have adequate knowledge to analyse problem in energy system. Company B has deficiency in all aspects. Company B does not have complete energy management team compare to company A. The energy management personnel are from maintenance team. Therefore, the 
objective of energy management is from maintenance perspectives that focus on supporting production. Consequently, the company does not have comprehensive energy policy. Furthermore, company B still use old production machines that are less efficient compare to newer machines in company A. The machines makes energy consumption in company $\mathrm{B}$ is higher than company $\mathrm{A}$. The condition also cause data integration problem in company B. Company B cannot implement real time IT system as the machine cannot support data connection. Consequently, energy management personnel have to collect energy consumption data manually. Those data are prone to error and missing. Therefore, the data are inadequate for review process.

Despite of limitation in company B, the company B can learn from company A to form energy management team consist of personnel from all company's department. Therefore, the company can analyse energy efficiency from many perspectives. Eventually, the company can have a comprehensive energy policy. Implementation of IT system to provide real time energy information benefits the company A to monitor, troubleshoot, and audit their energy system easily compare to company B. The paper shows that the utilisation of corporation energy performance rating can provide feedback to affiliated companies. So that the companies know current level of their energy performance compare to other similar companies. The companies can learn from other companies to improve their energy performance.

\section{References}

1. EIA. International Energy Outlook 2017. U.S. Energy Information Administration (2017)

2. Fahad M, Naqvi SAA, Atir M, Zubair M, Shehzad MM. Energy Management in a Manufacturing Industry through Layout Design. 8.168-74 (2017)

3. Franz E, Erler F, Langer T, Schlegel A, Stoldt J, Richter $\mathrm{M}$, et al. Requirements and Tasks for Active Energy Management Systems in Automotive Industry. Procedia Manufacturing, 8.175-82 (2017)

4. Telaga AS, Hartanto ID. Industrial energy efficiency practices in Indonesia: Lesson learned from astra green energy (AGen) award. IOP Conference Series Material Science Engineering, 180. (2017)

5. Bonfà $\mathrm{F}$, Salvatori $\mathrm{S}$, Benedetti M, Introna V, Ubertini S. Monitoring compressed air systems energy performance in industrial production: lesson learned from an explorative study in large and energy-intensive industrial firms. Energy Procedia, 143.396-403 (2017)

6. Dongellini M, Marinosci C, Morini GL. Energy Audit of an Industrial Site: A Case Study. Energy Procedia, 45.424-33 (2014) 